\title{
Fora do mundo: lugar e sentido da não-humanidade na ontologia fundamental
}

Marco Antonio Valentim - Universidade Federal do Paraná

\section{"Ou melhor"}

"O homem é história, ou melhor, a história é o homem"1 . Encerrando $O s$ conceitos fundamentais da metafísica: mundofinitude-solidão, essa sentença faz parte do último parágrafo da preleção, intitulado "O projeto como estrutura originária da formação de mundo". Nele, Heidegger considera a fundo a ideia de

${ }^{1} \mathrm{O}$ presente ensaio resulta da composição de dois outros anteriormente publicados como capítulos em coletâneas sobre a obra de Heidegger (Valentim, 2012a e Valentim, 2012b). Ambos os textos foram revisados e reformulados em muitos trechos, com vários acréscimos e subtrações, para formar em conjunto um único argumento exegético-crítico, mais denso e completo do que nas versões anteriores. 
que o projeto, o ser para possibilidades, que caracteriza o ser do "ente que nós mesmos somos", constitui a origem do acontecimento fundamental (Grundgeschehen), a saber, a formação de mundo (Weltbildung): "No projeto vigora o mundo [...]. O homem é uma passagem [Übergang], passagem como essência fundamental do acontecimento" (Heidegger, 2010, § 76, p. 531). Como que para eliminar qualquer dúvida possível sobre o sentido da tese que outorga ao homem, em sua essência projetiva, a condição de origem e centro do acontecimento histórico, o filósofo a enuncia concisamente naqueles termos. Contudo, se o homem é essencialmente determinado pela história, como entender, conforme a sentença sugere, que o acontecimento histórico se reduza ao fenômeno humano? Se "o homem é história", isto não poderia significar, ao contrário, que a história excede a esfera do homem? Por outro lado, se "a história é o homem", o significado de uma tal redução não poderia ser o da indicação de limites para a própria história, que seriam, precisamente, os do homem enquanto "formador de mundo"? E, sobretudo, qual é o lugar reservado por esse pensamento à não-humanidade enquanto aquilo que, através dos acontecimentos históricos e das decisões humanas, se mantém inapropriável pelo homem, irredutível à história e, possivelmente, reprimido por ambos? Não obstante seja quase omitida em Ser e tempo, a consideração do elemento a-histórico e não-humano pode ser decisiva para a discussão aprofundada do nexo entre humanidade e historicidade formulado na sentença heideggeriana. Talvez mesmo a conversão de sua primeira parte ("O homem é história") na segunda ("A história é o homem"), operada pela expressão "ou melhor", seja inspirada justamente por uma posição espiritual face a esse elemento. Afinal, o que faz, para Heidegger, com que seja me- 
lhor, de preferência a dizer que "o homem é história", afirmar que "a história é o homem", a não ser a necessidade de determinar o que é propriamente histórico a partir daquilo que distingue, quanto ao seu ser, o humano do não-humano? Com efeito, tal necessidade é claramente expressa pelo enunciado do problema filosófico geral da ontologia fundamental:

Como devemos determinar o ser do ente que nós mesmos somos e delimitá-lo [abgrenzen] frente a todo ser do ente não-dotado do modo de ser do ser-aí [des nichtdaseinsmässigen Seienden], de maneira a compreendêlo, não obstante, a partir da unidade de um conceito originário de ser? (Heidegger, 2005, p. 219).

Diante disso, cabe questionar se o "ser mesmo" (das Sein selbst) não consistiria senão no princípio geral de delimitação (Abgrenzung) da humanidade frente à não-humanidade.

\section{Ontologia cosmopolita}

Em Ser e tempo, encontra-se expressa e desenvolvida, sob a forma da analítica existencial, uma verdadeira ontologia da história. Ela é proposta nada menos que como fundamento para qualquer outra consideração ontológica e, em especial, para uma possível ontologia da natureza. Essa sua prerrogativa não se deve apenas ao fato de que, perfazendo uma fundamentação rigorosamente transcendental, a ontologia da história expõe as condições existenciais da possibilidade para toda e qualquer atitude humana em relação ao ente natural. Para Heidegger, o seu caráter fundamental radica, mais originariamente, na própria constituição de ser (Seinsverfassung) dos entes tematizados por ambas as ontologias. 
Com efeito, há em Ser e tempo a afirmação de uma precedência ontológica da história sobre a natureza, baseada no vínculo que cada qual mantém com a possibilidade do mundo enquanto caráter de ser do "ser-aí humano" (menschliches Dasein) que "determina o ente em seu todo" (Id. 2004a, p. 143). Uma vez que "a natureza mesma é um ente que vem ao encontro dentro do mundo" (Id. 1993, p. 63), e que a história originária (Urgeschichte) consiste na formação de mundo (Id. 2004a, p. 159), aquela jamais poderia tornar compreensível este último e, menos ainda, a própria história. Principalmente, Heidegger entende que o ser da natureza, que concebe como "caso-limite do ser de um possível ente intramundano" (Id. 1993, p. 65), se constitui em função do ser do ente que possui o mundo, isto é, o ser-aí: "O mundo pertence ao ser-aí humano, ainda que abarque todos os entes, e também o ser-aí, em sua totalidade" (Id. 2004a, p. 143). Com isso, a natureza não é senão o próprio ente "presente dentro do mundo", só que "não descoberto como tal" (Id. 1993, p. 65). Ao fazer-se manifesta, a natureza se vincula de imediato a uma possibilidade de ser do ser-no-mundo, sendo compreendida, como todo possível ente intramundano, "em vista do abrigo do ser-aî" (um-willen des Unterkommens des Daseins) (Ibid., p. 84). Poderíamos dizer, levando em conta o parentesco etimológico que a forma preposicional um-willen mantém com o verbo wollen (querer): a natureza quer (will) o acontecimento do mundo, ela intenciona a história.

De saída, observa-se nisso uma forte aproximação, talvez insuspeitada, à teleologia kantiana. Não é difícil auscultar, através da ontologia da história de Ser e tempo, o eco do pensamento central do opúsculo de Kant sobre a Ideia de uma história universal de um ponto de vista cosmopolita. Com o reconhecimento 
por Heidegger da solidariedade ontológica da natureza à história, não nos encontramos tão longe da pressuposição, legitimada originalmente pelo Apêndice à Dialética Transcendental da Crítica da razão pura, de uma conformidade a fins (Zweckmässigkeit) da natureza, mais precisamente, a sua conformidade à possibilidade de ser apropriada pela razão humana no conhecimento objetivo. Trata-se da ideia de que a natureza, até mesmo como adversária dos homens, impondo-lhe catástrofes e obstáculos, procede junto a eles segundo um propósito adequado ao desenvolvimento da cultura como formação humana (Bildung), colaborando, em última instância, para a sua destinação suprema, a racionalidade moral entendida como experiência de autonomia (cf. Kant, 1986, p. 12). Assim como, na ordem da gênese existencial, o ente da natureza, vindo ao encontro dentro do mundo, se deixa apropriar pelo ser-aí humano, assim também, na história universal, o ente natural serve à formação do homem cosmopolita - como se o mundo e a cultura pudessem constituir-se em vista de próprios, contrariamente ao seu enraizamento, empírico ou ôntico, na natureza.

A mera constatação desse ponto de aproximação entre Heidegger e Kant permite suspeitar que o projeto filosófico de Ser e tempo retoma positivamente o ideal moderno da Aufklärung (por mais extensa e intensa que seja a sua reformulação por Heidegger). Para reforçar essa suspeita, cabe lembrar que, em $D a$ essência do fundamento, Heidegger procura explicar o conceito existencial de mundo, entendido como aquilo em direção a que o ser-aí existe, assimilando-o explicitamente à ideia em sentido kantiano, referida na Dialética Transcendental como "representação de uma totalidade incondicionada", somente em vista da qual a experiência, enquanto relação ao objeto, pode se consti- 
tuir (Heidegger, 2004a, p. 146-155). Ao propor um tal vínculo entre o conceito existencial e a ideia transcendental de mundo na condição de concepções acerca daquilo para o que o ser-aí ultrapassa os demais entes, Heidegger avança na interpretação de Kant, apontando para a especificação, a seu ver genuinamente existencial, que o conceito de mundo experimentaria na Antropologia de um ponto de vista pragmático. Vislumbra-se a significação ontológico-existencial de mundo precisamente na noção cosmopolita de homem, lançada por Kant nessa obra:

O objeto mais importante no mundo, a que o homem pode aplicar todos os progressos na cultura, é o homem, pois ele é o seu próprio fim último. - Conhecêlo, portanto, como ser terreno dotado de razão segundo a sua espécie merece especialmente ser denominado conhecimento do mundo, embora ele perfaça apenas uma parte das criaturas terrenas. [...] Uma tal antropologia, considerada como conhecimento do mundo [...] ainda não é propriamente denominada pragmática quando contém um conhecimento ampliado das coisas no mundo, por exemplo, dos animais, plantas e minerais em diferentes países e climas, mas sim quando contém conhecimento do homem como $c i$ dadão do mundo (Kant, Antropologia de um ponto de vista pragmático, Prefácio, apud Heidegger, 2004a, p. 153-154).

Subscrevendo a orientação antropocêntrica do conceito kantiano, Heidegger arremata seu comentário à Antropologia pragmática com a seguinte afirmação: "Mundo é, em tudo isso, a designação para o ser-aí humano no cerne de sua essência" (Hei- 
degger, 2004a, p. 154).

Aparentemente, jamais se poderia encontrar no "cerne da essência do homem" algum vestígio da natureza pretendida como exterior ao mundo e, portanto, como a-histórica. Sabe-se que, segundo Ser e tempo, a historicidade (Geschichtlichkeit) constitui o ser mesmo do homem, o ser-aí enquanto ser-no-mundo, em sua extensão originária (ursprüngliche Erstreckheit), mais ampla e concreta (Id. 1993, §§ 72, 75). Não se trata apenas de que o homem esteja sujeito à história; trata-se, antes, de que ele é, em seu ser, histórico (geschichtlich) e, mais ainda, o único ente propriamente histórico dentre todos os que ele mesmo pode compreender em vista de suas possibilidades de ser. A partir disso, podemos perceber uma tomada de posição cuja obviedade não desmente a sua importância nem a sua problematicidade no pensamento de Heidegger: ao atribuir à história uma dignidade ontológica talvez inaudita, a analítica existencial a circunscreve, com esse mesmo gesto, à esfera do homem. Em sentido estrito, essa esfera, Da-sein, é entendida como o âmbito unicamente em que o ser dos entes em geral se dá a compreender e, portanto, que os demais entes, os "não-dotados do modo de ser do ser-aî" (nichtdaseinsmässig), devem pressupor, a fim de manifestar-se como os entes que são - inclusive, como natureza primitiva e imemorial. Desse modo, tudo o que é só pode ser e fazer sentido "no" ser-aí como âmbito do poder de compreensão que, por meio da apropriação do que vem ao encontro (ocupando-se disso, dominando-o, sujeitando-se-lhe ou estranhando-o), desencadeia o movimento da história enquanto acontecimento originário e total do seu próprio ser:

Acontecer da história é acontecer do ser-no-mundo. [...] Tão logo o ser-aí existe faticamente, também já 
vem ao encontro o descoberto dentro do mundo. Com a existência do ser-no-mundo histórico, tanto o manual [zuhanden] quanto o subsistente [vorhanden] estão sempre já inseridos na história do mundo. Instrumento e obra, os livros, por exemplo, têm seus "destinos", construções e instituições têm sua história. Mas também a natureza é histórica [geschichtlich]. Sem dúvida, ela não o é na medida em que falamos de "história da natureza", e sim como paisagem, região de ocupação e exploração, como campo de batalha e lugar de culto. Esse ente intramundano [a natureza] é como tal histórico, e sua história não significa algo "exterior" que acompanha simplesmente a história "interior" da "alma" (Id. 1993, p. 388-389).

Logo, se "o acontecer da história é o acontecer do ser-nomundo", ou seja, se "a história é o homem", o ser-aí encontra-se, em cada época, situação e circunstância, destinado essencialmente a si mesmo, de preferência a todo e qualquer ente nãohumano. Existindo, o ser-aí humano transcende a totalidade do ente na direção de sua possibilidade mais própria de ser, trazendo consigo, como sua pertença ("como paisagem, região de ocupação e exploração, como campo de batalha e lugar de culto"), tudo aquilo que ele "ultrapassa": a não-humanidade, a natureza (Cf. Id. 2004a, p. 138-139). A história mesma se confunde com esse destino (Schicksal) de ultrapassagem, o qual, embora seja eminentemente relativo ao ser-aí humano, "vale também, de certo modo, para as "catástrofes naturais"' (Id. 1993, p. 389). 


\section{O enigma do acontecimento}

Apesar de tal desequilíbrio ontológico entre natureza e história, não deixa de parecer problemático ao filósofo o "caráter próprio de movimentação [Bewegtheit]" que sucede ao ente nãodotado do modo de ser do ser-aí, quando de sua entrada na história. Se esse ente é destituído de historicidade, como pode participar da história e suportá-la, na condição de paisagem ou lugar do acontecimento humano? Como acontece à natureza entrar na história, isto diz respeito ao "enigma ontológico da movimentação do acontecer em geral" (Ibid., p. 389): o "enigma do ser", ou seja, "o enigma do movimento de sua essência" (Ibid., p. 392). É sabido, porém, qual seja a condição fundamental do acontecimento que carrega consigo a totalidade do ente intramundano, natural ou cultural:

A historicidade própria compreende a história como o "retorno" do possível e sabe, por isso, que a possibilidade só retorna quando, de forma instântaneo-destinal [schicksalhaft-augenblicklich], a existência está aberta para ela na retomada resoluta (Ibid., p. 391-392).

Em outros termos, a história tem por origem primeira o projeto próprio de possibilidades da existência, que constitui o núcleo do ser do ser-aí: a "estrutura originária da formação de mundo". O enigma equivale, em certa medida, ao "problema da possibilidade interna da compreensão de ser" (Id. 1991, p. 237), o qual deve poder resolver-se no escopo da "analítica ontológicofundamental do ser-aî" (Ibid., p. 237). Se, por um lado, a tomada do projeto como origem da história não significa a abstração pura e simples da vinculação fática do ser-aí com o ente que ele não é, ela implica, por outro, que esse vínculo - a factici- 
dade (Faktizität) da existência, caráter de ser pelo qual o ser-aí é "em" um mundo - deva ser interpretado como tornado possível, em última instância, pela propriedade (Eigentlichkeit) do ser-aí mesmo. A resolução do "enigma ontológico do acontecer em geral" parece depender, antes de mais nada, do reconhecimento do "abismo metafísico" (Id. p. 172) que isola o homem dos entes que vêm ao encontro dentro do mundo, como aquele único que guarda em si a possibilidade ontológica de todos os demais.

Sob essa perspectiva, o enigma da história se reduz, fundamentalmente, à questão de como é possível "a unidade essencial" que o projeto mantém "com a disposição e o estar-lançado" (Id. 1991, p. 235), ou seja, com a facticidade do ser-aí. Em formulação mais estrita e complexa, que remete diretamente ao conceito de existencial de história, trata-se, em Ser e tempo, de saber qual momento da estrutura da temporalidade ekstática do ser-aí - o porvir ou o ter-sido - possui a prerrogativa na constituição ontológica do destino:

Manifestamente, o ser-aí nunca pode ter passado, não porque ele não passe, mas porque essencialmente ele nunca pode ser presente-subsistente; antes, se é, ele existe. Em sentido rigorosamente ontológico, o ser-aí que não mais existe não passou, mas tem sido-aí. As antigüidades ainda simplesmente dadas possuem um caráter "passado" e histórico com base em sua pertinência instrumental e proveniência de um mundo sido de um ser-aí sido-aí. Isso é o primordialmente histórico. Mas será que o ser-aí só se torna histórico pelo fato de não ser mais aî? Ou será que ele é histórico justamente na medida em que existe faticamente? Será o ser-aí apenas sido no sentido do sido-aí, ou ele é sido 
como porvir que torna presente, isto é, na temporalização da temporalidade? (Id. 1993, p. 380-381).

Com esses termos, Heidegger parece perguntar se a história acontece primariamente (primär) a partir do projeto de si ou da facticidade do ser-no-mundo, ou seja, a partir da possibilidade da existência própria ou do vínculo que, atando o ser-aí ao ente que ele não é, o condena à impropriedade (Uneigentlichkeit) de si mesmo.

Qual é, afinal, a dimensão originária do acontecimento histórico: a que desde logo "destranca" a existência, outorgando-lhe a possibilidade da auto-apropriação (o "estar-resolvido", Entschlossenheit), ou a que lança o existir em uma situação (o "estarlançado", Geworfenheit), retendo-o junto àquilo que, enquanto vetor da decadência (Verfallenheit), obsta essencialmente o seu tornar-se próprio? Como a história acontece é uma questão cuja resposta depende, sobretudo, do modo como o ser-aí, por assim dizer, está para si mesmo: desde o seu futuro ou desde o seu passado. Embora se trate de dimensões cooriginárias (projeto e facticidade), seria preciso determinar a partir de qual delas a unidade de essência do existir se constitui, uma vez que dirigem a existência em sentidos opostos: própria ou impropriamente, para si mesma ou em direção ao não-existente.

\section{Vida ou morte}

Por mais acirrado que se torne o referido enigma, é certo que a analítica existencial procura solucioná-lo com base na ideia do "primado ôntico-ontológico" (cf. Ibid., 1993, §§ 3-4) da existência e, manifestamente, em favor da possibilidade, suprema para o ser-aí, de seu ser-próprio. De fato, em uma importante 
passagem do $\S 74$ de Ser e tempo ("A constituição fundamental da historicidade"), Heidegger evoca os existenciais do ser-paraa-morte e da decisão antecipadora, vinculados estreitamente ao aspecto projetivo do existir, para determinar o lugar da facticidade do ser-aí na constituição da história:

Se, porém, o destino constitui a historicidade originária do ser-aí, então a história não tem seu peso essencial no passado, nem no hoje e nem em seu "nexo" com o passado, mas sim no acontecer próprio da existência, que irrompe do porvir do ser-aí. Enquanto modo de ser do ser-aí, a história tem suas raízes tão essencialmente no porvir que a morte, enquanto possibilidade caracterizada do ser-aí, relança a existência antecipadora para o seu estar-lançado fático e somente então confere ao ter-sido o seu primado característico no histórico. O ser-para-a-morte próprio, isto é, a finitude da temporalidade, é o fundamento oculto da historicidade do ser-aí (Heidegger, 1993, p. 386).

Implícita nessa passagem, convém destacar sobretudo a tese de que, sendo para a sua possibilidade mais própria, aberta com a antecipação da morte, o ser-aí humano torna ele mesmo possível a situação fática a que desde logo se encontra lançado: "O ser-aí torna possível para si mesmo - testemunhando o seu poder-ser mais próprio - a sua existência fática" (Ibid., p. 300).

Para retomarmos uma formulação de Haar, trata-se da tese de que "só há situação para um ser-aí resoluto" (Haar, 1990, p. 56): "irrompendo do porvir do ser-â̂", a historicidade consiste, originariamente, no movimento de "possibilitação da situação concreta" da existência enquanto "autopossibilitação do ser-aî" 
(Ibid., p. 39-43). Contudo, segundo o intérprete, ao tornar possível para si mesmo a sua situação fática, o ser-aí recalca no projeto de si o seu próprio "estar-lançado fático", o "fundo opaco e inexplorável do destino" (Ibid., p. 73). Haar pretende apontar para uma dimensão insondável do existir, a de uma facticidade que não seria possibilitada pelo projeto existencial:

Ora, o que jaz no fundo do destino é o passado originário do estar-lançado (Geworfenheit), a possibilidade radical da facticidade. É preciso distinguir aqui - distinção que não é sempre clara nos textos - a facticidade enquanto compreensão inautêntica de si como uma coisa ou ente-subsistente e a facticidade enquanto compreensão autêntica, mas obscura, da ligação íntima entre o ser-aí e o ente-subsistente, o qual, de algum modo, ele mesmo é igualmente! A Geworfenheit constitui, com efeito, o fundo opaco e inexplorável do destino. Nenhum projeto de repetição, mesmo que o assumisse inteiramente, poderia esclarecê-lo em definitivo (Ibid., p. 73).

Trata-se, mais precisamente, da facticidade da vida (Leben), "uma natureza mais velha em nós do que as nossas possibilidades intramundanas" (Ibid., p. 76), como uma condição que jamais poderia ser afastada nem apropriada pelo ser-aí. Vida, nesse sentido, significaria o fato irremissível de ser cativo de algo "originalmente extra-mundano" (grifo meu), que "resta, quanto à sua origem, absolutamente fechado" para o próprio ser-aí (Ibid., p. 75).

Mais ainda, justamente em virtude do compromisso de primeira ordem, firmado pela ontologia de Ser e tempo, com a pos- 
sibilidade da auto-apropriação da existência em seu todo, parece que "a origem da facticidade, da Geworfenheit, deve permanecer, para Heidegger, indeterminada" (Ibid., p. 41). De fato, nas poucas ocasiões em que alude, em Ser e tempo, ao fenômeno da vida, Heidegger tende a reduzi-lo ao ser-no-mundo, sem pronunciar-se sobre sua possível originariedade enquanto fenômeno irredutivelmente diverso:

Vida é um modo próprio de ser, porém essencialmente acessível apenas no ser-aí. A ontologia da vida realizase seguindo o caminho de uma interpretação privativa; ela determina o que deve ser a fim de que algo como somente-viver possa ser. A vida não é simples subsistência, mas também não é ser-aí (Heidegger, 1993, p. 50). A constituição ontológica fundamental de "viver" é, porém, um problema peculiar que só pode ser desenvolvido através de uma privação redutiva a partir da ontologia do ser-aí (Ibid., p. 194).

Vê-se aí, suposta como acessível apenas "no" ser-aí, situada ontologicamente a meio caminho entre subsistência e existência, e tomada de modo positivo como determinação correlativa da morte fisiológica que, além de animais e plantas, atinge também o ser-aí, mas em que ele nunca é propriamente (eigentlich), que a vida só se deixa compreender como um modo "próprio" (eigen) de ser sendo privada de possibilidades exclusivas do ser-aí humano. Assim como a natureza consiste no "caso-limite do ser de um possível ente intramundano", tendo fundamento ontológico na mundanidade, a vida humana se determinaria como "caso-limite do ser de um possível ser-no-mundo", adquirindo sentido apenas a partir da morte existencial, na condição de 
"solo" favorável à autopossibilitação do ser-aí.

Obviamente, para Heidegger, não é válida a recíproca, pela qual se tentaria pensar a essência do homem a partir da vida: "O ser-aí não pode ser ontologicamente determinado tomando-se-o como vida - (ontologicamente indeterminada) e, para além disso, ainda como algo outro" (Ibid., p. 50). Concebendo o homem como animal dotado de razão, ou mesmo, como espírito que, contudo, padece o fato de ter nascido, descreve-se, no limite, algo rigorosamente impossível do ponto de vista ontológico-existencial: a facticidade como origem do projeto. Determinar o ser-aí como vivente implicaria, no limite, alterá-lo radicalmente, perdendose com isso a reivindicada unidade de essência entre projeto e facticidade. Tal unidade seria possível e discernível unicamente a partir do primeiro: conforme formulam, poucos anos depois, os Conceitos fundamentais da metafísica, a obrigatoriedade (Verbindlichkeit), enquanto forma do vínculo fático com o ente em geral, "sempre pressupõe uma possibilitação [Ermöglichung]", isto é, o próprio projeto, que "é em si o acontecer que deixa irromper a obrigatoriedade enquanto tal" (Id. 2010, p. 528). Isso parece querer dizer que o ser-aí humano jamais poderia se experimentar como lançado em uma situação que ele não pudesse previamente apreender como sua e na qual não pudesse reconhecer o drama espontâneo de seu próprio ser. Torna-se assim evidente que, no contexto existencial, a facticidade, que abre e vincula o ser-aí a outrem, assume estatuto ontológico de fundado (fundiert), sendo compreendida em vista da propriedade do ser-aí, o ser-para-a-morte, enquanto fundamento do possível em geral.

Frente a tudo isso, caberia perguntar (por mais que, eventualmente, o discurso de Heidegger não nos autorize a fazê-lo), 
se a vida ontologicamente indeterminada é mesmo ontologicamente determinável. Isto porque, se se mantêm juntas, contra o aparente sentido da ênfase do texto heideggeriano, a noção, tão "decadente" quanto concreta, de que o ser-aí humano vive, de um lado, e a tese ontológica segundo a qual ele não pode ter o seu ser concebido existencialmente a partir do fenômeno da vida, de outro, impõe-se de maneira inevitável a questão sobre se o homem enquanto vivente pode ser tema de uma consideração ontológica. Trata-se de questionar se a não-humanidade - nela compreendidos a natureza e a vida, a natureza viva (lebendige Natur) e o vivente "humano" - constitui um âmbito realmente acessível à ontologia fundamental.

\section{Naturereignisse}

Tomemos, como ponto de partida para o desenvolvimento dessa questão, uma passagem do $\S 32$ de Ser e tempo dedicada à explicação de um dos conceitos fundamentais da analítica existencial, o conceito de sentido (Sinn). Entendido como o foco (o "em-direção-a-quê", das Woraufhin) do projeto da existência, desde o qual, unicamente, algo se torna compreensível (verständlich) como algo, sentido, afirma Heidegger, é "um existencial do ser-aí, e não uma propriedade colada sobre o ente" (Heidegger, 1993, p. 151). Ao ingressar no mundo enquanto contexto ontológico presidido pelo ser-aí, o ente em geral "adquire" o sentido pelo qual se constitui o seu próprio ser. Para o filósofo, isso implica pelo menos duas coisas: que "somente o ser-aí pode ser pleno de sentido ou carente de sentido [sinnvoll oder sinnlos]" (Ibid., p. 151), pois só ele se determina em seu ser como compreensão, isto é, em relação constitutiva com a possibilidade mesma do sentido; e que "todo ente não-dotado do modo de 
ser do ser-aí [alles Seiende von nichtdaseinsmässiger Seinsart] deve ser concebido como sem sentido [unsinnig], essencialmente isento do sentido em geral" (Ibid., p. 152), uma vez que seria essencialmente desprovido daquele poder de compreensão.

Dessa maneira, a diferença entre o Dasein e o ente nichtdaseinsmässig é posta de modo radical. Trata-se da diferença entre o ente, por assim dizer, "sinnig", que pode ser pleno ou carente de sentido, mas que é sempre em relação com o sentido, e o ente unsinnig, absolutamente estranho à possibilidade do sentido, ao qual, portanto, o sentido não pode sequer faltar. Heidegger parece assim considerar o ente não-dotado do modo de ser do Dasein como que "em si mesmo", como se guardasse, a despeito de seu aspecto intramundano, um traço fundamental de incompreensibilidade, pelo qual resistiria à "mundanização" a que está sujeito quando de sua apropriação pelo ser-aí.

Sem discutir, por ora, a inegável tensão entre essa ideia e certas teses nucleares da analítica existencial (por exemplo, a de que todo ente só é "em si mesmo" o que é e como é na medida em que "vem ao encontro dentro do mundo"), interessa destacar a surpreendente consequência derivada por Heidegger de tal formulação, ao nosso ver mais forte, da diferença entre o ser-aí e o não-ser-aí. Diz ele, enfaticamente: "Somente o que é sem sentido [unsinnig] pode ser contrassensual [widersinnig]" (Ibid., p. 152). Precisamente por não se determinar em função da possibilidade do sentido, nem sequer pela falta deste, o ente $n i$ chtdaseinsmässig pode algo de que o próprio Dasein seria essencialmente incapaz: ser contra a possibilidade do sentido. Mais que de Nicht-dasein, tratar-se-ia, portanto, de Un-dasein: algo, digamos, "mais" negativo e ameaçador para o ser-no-mundo do que consegue ser o ente intramundano quando, por exemplo, 
furtando-se ao uso, impele o ser-aí a atentar para o seu próprio mundo (cf. Ibid., p. 72-76).

Felizmente, o filósofo oferece um exemplo geral dessa capacidade aparentemente insólita do ente intramundano, a de ser contrário à sua compreensibilidade pelo ser-no-mundo - exemplo de grande relevância para nossa discussão:

O subsistente pode, como aquilo que vem ao encontro no ser-aí, igualmente assaltar o seu ser [gegen dessen Sein gleichsam anlaufen], como, por exemplo, eventos da natureza [Naturereignisse] que irrompem e destroem (Heidegger, 1993, p. 152).

Particularmente notável no exemplo aduzido é que Heidegger se refere ao "assalto" do ser-aí pelos "eventos da natureza" não simplesmente como um desastre ôntico, mas como uma catástrofe genuinamente ontológica. Pois é o ser mesmo do ser-aí enquanto compreensão existencial que pode ser assaltado pelo ente subsistente, nisto consistindo o possível caráter contrassensual deste último: a capacidade de colocar-se contra a possibilidade do sentido, contra o ser da compreensão de ser. O exemplo oferecido parece supor que a natureza seja capaz de atingir (e, com isso, destruir ou amparar) decisivamente o próprio mundo enquanto determinação ontológica do ser-aí, como que de fora deste - e isto justamente na medida em que ela vem ao encontro, sob o aspecto de instrumento, coisa ou objeto, dentro desse mesmo mundo (como escreve Heidegger, "no" ser-aí). Ou seja, a natureza possuiria também uma face oculta, inacessível à descoberta, pelo qual se tornaria capaz de manter-se irredutivelmente inapropriável por um projeto de existência. Essa inapropriabilidade fundamental é que lhe permitiria tanto sustentar e pro- 


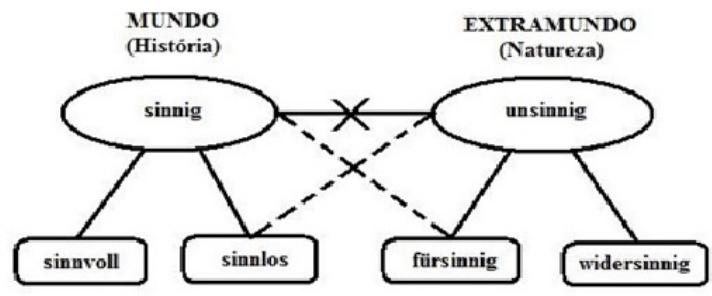

Observação: As linhas pontilhadas designam vetores de mútua transformação entre esses contextos ontológicos fundamentalmente divergentes.

ver a formação de mundo (fürsinnig) quanto impor resistência e adversidade, como fonte de catástrofe (widersinnig), a esse acontecimento.

Tentemos representar, mediante um esquema gráfico, o conteúdo de nosso comentário, a fim de poder divisar com mais clareza os elementos e as relações em jogo (relativos, todos eles, à possibilidade do sentido "em geral"):

Sem dúvida, seria enormemente difícil conceber a possibilidade ontológica deuma adversidade imposta pela natureza ao ser mesmo do homem. Não é de estranhar que, do ponto de vista da analítica da existência, isso aparentemente não faça sentido, sequer como mera possibilidade. Em testemunho, a sequência imediata da passagem acima citada do $\S 32$ de Ser e tempo diz claramente:

E se perguntamos pelo sentido de ser, então a investigação não assume um sentido profundo [tiefsinnig] nem rumina o que estaria atrás do ser, mas pergunta por ele mesmo, na medida em que ele adentra a compreensibilidade do ser-aí. O sentido de ser não pode 
nunca ser contraposto ao ente ou ao ser como "fundamento" de sustentação do ente, pois "fundamento" só se torna acessível como sentido, ainda que ele mesmo seja o abismo da falta de sentido (Ibid., p. 152).

Ao argumentar em favor do fato de o sentido ser incontornável em toda relação para com o ente, esse trecho desmente a aparente inefabilidade do ser, fechando de antemão o caminho para uma possível ontologia da natureza enquanto região ontológica da qual o sentido estaria de todo ausente. Afinal, trata-se daquilo que faz exceção e possível oposição à esfera mesma da compreensibilidade!

\section{Fora do mundo}

Consistentemente, em todo o restante de Ser e tempo, Heidegger jamais reconhece ao ente nichtdaseinsmässig, pelo menos de maneira expressa, uma tal função contra-ontológica, isto é, a de atingir o ser do ser-aí e determinar decisivamente a possibilidade do sentido. É como se, por princípio, esse ente não pudesse ter nenhum papel determinante junto à "relação de ser" (Seinsbeziehung) que o ser-aí mantém consigo mesmo enquanto compreensão existencial. O ente sem sentido seria como que entregue, pela ontologia da existência, à serventia do ser-aí, sendo compreendido por este sempre "em vista" (um-willen) de si mesmo. Diante disso, é provável que a expectativa de ver atribuída alguma função ou lugar à natureza enquanto potência do nãosentido seja em si mesma descabida. Se, conforme propõe Ser e tempo, o campo do sentido equivale à esfera da compreensão ontológica, aquilo que escapa ao primeiro deve, por isso mesmo, manter-se inacessível a esta última. Desse ponto de vista, a 
limitação da ontologia ao mundo existencialmente concebido explicaria não só a predominância do mundo sobre a natureza, mas também, sobretudo, a necessária omissão de todo possível elemento exterior ao mundo na discussão a respeito da constituição (e, eventualmente, da desagregação) das estruturas e dos fenômenos existenciais. De fato, certas vezes em que Heidegger, na continuidade do projeto filosófico de Ser e tempo, retorna à consideração do suposto "ser" da natureza, tendo que rever teses centrais da sua obra, a questão dos limites da ontologia, ou seja, da própria compreensão ontológica, vem à tona.

Uma dessas ocasiões surge já na preleção do semestre de verão de 1927, ministrada em Marburg, sobre Os problemas fundamentais da fenomenologia. A certa altura de uma longa retomada da analítica existencial, no contexto de uma reconstituição crítica da "tese da ontologia moderna sobre o ser", Heidegger reconsidera a afirmação da intramundanidade da natureza proposta no $\S 14$ de Ser e tempo, onde ela se enunciava claramente como uma tese ontológica, a de que a natureza constitui um "caso-limite do ser de um possível ente intramundano" (Heidegger, 1993, § 14, p. 65). Nos Problemas fundamentais, a mesma tese é reafirmada, porém com o acréscimo de um esclarecimento que parece modificar consideravelmente o seu sentido: Heidegger diz, aliás por várias vezes, que "a intramundanidade não pertence ao ser da natureza" (Id. p. 240), isto é, que ela "sucede" (fällt zu) à natureza enquanto e somente enquanto esta ingressa no mundo. De maneira semelhante, afirma, a intramundanidade também não pertence necessariamente ao ser do ser-aí, determinado de modo próprio como ser-no-mundo. Enquanto determinação "ontológica", ela incidiria tão-somente sobre o "trato" (Umgang) com o ente, sendo uma "determinação necessária para a possibilidade 
da descoberta da natureza" (Ibid.). Indo ainda mais longe, o filósofo chega mesmo a aventar que a intramundanidade não seria sequer "a estrutura de um ser" (die Struktur eines Seins), como, por exemplo, o ser-no-mundo é "uma estrutura essencial do ser do ser-aî"; todavia, "por precaução", prefere dizer simplesmente que "ela não pertence ao ser da natureza" (Ibid., p. 241).

Tentemos explorar o sentido possível da tese motivada por essa precaução. Propor, como faz Heidegger, que a intramundanidade, enquanto aquilo que sucede ao ente ao ser descoberto pelo ser-aí, não consiste propriamente em uma "estrutura de ser" significa, ao menos à primeira vista, adotar um ponto de vista crítico-transcendental, sob o qual se reconhece a impossibilidade de acesso ao ente tomado como independente de sua compreensibilidade. Assim como, para Kant, as categorias não equivalem a determinações das "coisas em si mesmas", mas simplesmente a formas a priori pelas quais nós, homens, as representamos na condição de objetos, assim também (em que pese a divergência de Heidegger para com Kant a respeito do ser do homem e de qual seria o modo adequado de concebê-lo), a intramundanidade não consistiria em uma determinação do ser da natureza, mas "tão-somente" na forma originária da relação do ser-aí com o ente que vem ao encontro dentro do mundo. Com efeito, Heidegger diz expressamente: "Mundo é somente se e enquanto um ser-aí existe. A natureza pode ser também se não existe nenhum ser-aí [wenn kein Dasein existiert]" (Ibid., p. 240).

Vale notar que a indicação da possibilidade ontológica do extramundano, entendido aqui (provisoriamente) como o ser "em si" de um ente, contraria literalmente o que Heidegger considera a tal respeito, nos $\S \S 15$ e 16 de Ser e tempo. Ao fim do primeiro, ele sustenta a tese de que a "manualidade" (Zuhande- 
nheit), ou seja, o modo de ser do ente intramundano enquanto termo do comportamento ocupacional do ser-aí, "é a determinação ontológico-categorial do ente como ele é 'em si"' (Id. 1993, p. 71). Quer dizer, considerado em si mesmo, o ente intramundano é instrumento manual (zuhanden) do ser-aí; trata-se do ente "mundanizado" enquanto tal, descoberto e apropriado pelo ser-aí em função de seu existir. Porém, em que consiste precisamente o ser "em si" do ente manual? Responde-se a essa pergunta no parágrafo seguinte, no contexto de uma exposição da possibilidade de gênese do subsistente (vorhanden) a partir da ocupação com o manual. Heidegger diz que manter-se em si significa, para esse ente, "não sair da sua não-surpresa", isto é, conservar-se no "nexo referencial" aberto pela ocupação (Ibid., p. 75). A condição de possibilidade para tanto é "o não-anunciar-se do mundo" (das Sich-nicht-melden der Welt): para que o manual possa ser em si, é preciso que o mundo, em significação ontológico-existencial, permaneça oculto para o próprio ser-aí, que existe sempre já em direção a ele (Ibid., p. 75-76). A relação estrutural do ser-aí com o seu mundo é, pois, ontologicamente anterior ao vínculo ocupacional que o ata ao ente que vem ao encontro como instrumento dentro do mesmo mundo. Donde Heidegger pode concluir que "o ser-em-si [das An-sich-sein] do ente intramundano só se torna apreensível com fundamento no fenômeno do mundo [des Weltphänomens]" (Ibid.).

Do ponto de vista ontológico-existencial, não faria sentido atribuir à natureza, ou a qualquer outro ente possível, o estatuto de "em si" enquanto "fora do mundo", uma vez que, na gênese do sentido, o encontro primeiro com o não-ser-aí é determinado pela relação mais originária que o ser-aí mantém com um mundo cuja condição de possibilidade não pode ser dada por nenhum 
ente que vem ao encontro dentro dele, mas somente pelo projeto do próprio ser-no-mundo. Se os entes só são "em si" já dentro e a partir do mundo, a possibilidade ontológica do "fora" - que, todavia, nos Problemas fundamentais, Heidegger parece aceitar pelo menos como questão - não passaria do resultado da operação derivada de "desmundanização" (Entweltlichung) a que é sujeito o manual intramundano quando da "quebra" do nexo referencial da ocupação, convertendo-se assim em ente subsistente, "constatável tematicamente" (Heidegger, 1993, p. 75). Operada pelo "comportamento teórico" (theoretisches Verhalten) em sua fuga decadente para dentro do mundo, para junto da "realidade" (Realität), a desmundanização dá lugar não àquilo que se excetua à compreensibilidade do ser-no-mundo, e sim a um outro modo da intramundanidade, de ser e fazer sentido dentro do mundo: a Vorhandenheit (subsistência, disponibilidade). Isso vale exemplarmente para a própria natureza, tomada, no sentido da analítica existencial, como "caso-limite do ser de um possível ente intramundano". Para a natureza, não ser compreendida como "algo apenas subsistente", vorhanden, significa simplesmente ser como ente manual, zuhanden:

Natureza não deve, contudo, ser aqui compreendida como algo apenas subsistente - também não como poder da natureza. A floresta é reserva, a montanha pedreira, o rio represa, o vento é vento "nas velas". Com o "mundo circundante" descoberto, assim vem ao encontro a "natureza" descoberta. Pode-se abstrair de seu modo de ser como manual; ela mesma pode ser descoberta e determinada simplesmente em sua pura subsistência e disponibilidade. A esse descobrir da natureza fica, porém, encoberta a natureza tam- 
bém como aquilo que "tece e acontece", precipita-se sobre nós, cativa-nos como paisagem. As plantas do botânico não são flores no campo, o "jorrar" geograficamente fixado de um rio não é a "fonte no solo" (Ibid., p. 70).

Com iso, percebemos que, na passagem de Ser e tempo aos Problemas fundamentais da fenomenologia, o filósofo oscila entre a concepção da natureza como ser de um possível ente intramundano, que só é "em si" a partir do mundo (a "natureza do mundo circundante", Umweltnatur), e a admissão da possibilidade de uma natureza cujo ser não é determinado pela intramundanidade e, principalmente, nem mesmo em vista do mundo (será isto, aliás, o que, na passagem citada, quereria designar a expressão "poder da natureza", Naturmacht?). Parecem assim chocar-se duas posições distintas sobre os limites da compreensão ontológica: coincidem eles com os do mundo existencialmente concebido ou ultrapassam essa esfera? Como a ontologia fundamental resolve tal conflito, se é que se trata mesmo de um?

\section{Três teses}

No $§ 10$ da última preleção de Marburg, do semestre de verão de 1928, publicada sob o título Princípios metafísicos da lógica a partir de Leibniz, Heidegger retoma o problema do "em si". Ao concluir um longo desenvolvimento sobre "O problema da transcendência e o problema de Ser e tempo", formula sumariamente três teses ("Hierzu drei Thesen") basilares da ontologia fundamental, propondo uma certa hierarquia entre elas, bem como entre os elementos nelas em jogo (ser, ente e ser-aí). Em uma 
retomada quase literal da ideia da independência do ser da natureza em relação ao mundo lançada nos Problemas fundamentais, a primeira dessas teses afirma, com todas as letras, a possibilidade ontológica do "em si": "Ente é em si mesmo o ente que é e como é, também se, por exemplo, o ser-aí não existe" (Heidegger, 1990, p. 194). Note-se que o fato de o ser-aí ser referido como exemplo (" $z$. B.") por referência ao qual se confirmaria a independência do ente em si mesmo parece, de início, somente acirrar a constatação da relatividade ontológica do ser-aí frente ao ente não-dotado do seu modo de ser, ao não-ser-aí.

Por sua vez, a segunda tese propõe a diferença entre ser e ente (explicitamente nomeada "diferença ontológica" nesse parágrafo da preleção) e, como estreitamente ligada a ela, a dependência do próprio ser em relação ao ser-aí: "Ser não 'é', mas só há ser [gibt es] enquanto o ser-aí existe" (Ibid., p. 194). A tese é seguida por uma breve explicação: "Na essência da existência jaz transcendência, isto é, dar[-se] de mundo [Geben der Welt] prévio e em favor de todo ser para e junto ao ente intramundano" (Ibid.). Isto quer dizer que a relação do ser-aí ao ser, em cujo âmbito somente o ser "se dá", é equivalente à precedência do mundo em relação a todo comportamento existencial dirigido ao ente. Afora o fato de que, formulada nesses termos, a explicação se inclina à identificação entre ser e mundo, intensificando assim a dependência do ser em relação ao ser-aí, ela parece, ademais, conflitar com o que fora proposto pela primeira tese. É que a precedência do mundo em relação ao ser-junto ao ente intramundano implica também a precedência do ser-no-mundo em relação ao próprio ente intramundano, do ser-aí em relação ao não-ser-aí. Se o ente só pode ser em si a partir do mundo, não seria o ente que é e como é, caso o ser-aí, enquanto formador 
de mundo, não existisse: rigorosamente falando, esse ente não teria ser, não "seria" propriamente um ente.

A lembrança da tese problemática introduzida nos Problemas fundamentais (a de que "a intramundanidade não pertence ao ser da natureza") poderia provocar uma forte advertência contra a interpretação proposta, não fosse, contudo, a última das três teses enunciadas: "Somente enquanto o ser-aí existente se dá a si mesmo algo como ser, pode o ente manifestar-se em seu em si, ou seja, pode a primeira tese ser compreendida e reconhecida" (Ibid., p. 195). Essa terceira tese perfaz a articulação entre as duas primeiras, propondo que a "compreensão de ser" (Seinsverständnis), que Heidegger chama também de "transcendência originária" (Urtranszendenz; Ibid., p. 194), é condição da possibilidade ontológica do "em si", bem como da "transcendência ôntica". Que a inteligibilidade da primeira tese esteja subordinada à da terceira significa, pois, que a independência do ente em si mesmo é, por assim dizer, "dependente" da dependência do ser em relação ao ser-aí. Porque o ser do ente só se dá no ser-aí, o ente é "em si" apenas para o ser-aí, como ente junto ao qual ele existe. Sem constituir genuína exceção ao mundo enquanto esfera da compreensibilidade, o ser-em-si do ente é, portanto, tão-somente um modo de o ente vir ao encontro dentro do mundo, uma forma de intramundanidade.

Não poderia ser de outra maneira, uma vez que, conforme o Nota Bene que se segue ao enunciado das três teses, "o ser se dá originariamente e em si se torna acessível o seu ente" (Ibid.). Ora, tornar acessível o ente é torná-lo compreensível, apropriável, pelo ser-aí, no qual somente "há ser". "Originariamente", o ser é o fundamento da compreensibilidade do ente em geral, tanto do ser-aí quanto do ente nichtdaseinsmäßig, pelo próprio 
ser-aí: ser "é" sentido. É esta "ideia do ser" que parece comandar a articulação entre as três teses comentadas. Sob essa ideia, Heidegger pode concluir no mesmo Nota bene: "Com respeito a esse ente [tornado acessível pelo ser], não se pode questionar, nem mesmo em si, quanto ao seu ser em si" (Ibid., p. 195).

Não é, contudo, imediatamente claro o que se afirma com essa conclusão, que poderia admitir pelo menos dois significados. Ou, como Heidegger diz no mesmo trecho, "conhecemos sempre apenas o ente, mas nunca ser sendo [seiendes Sein]" (Ibid.), de modo que o ser-em-si de um ente, isto é, o ser do ente separado desse mesmo ente, equivaleria, em razão da própria diferença ontológica, a uma rigorosa impossibilidade: "[...] a questão sobre o que seja o ser no ente que é em si [am An-sich-seiendes] não tem nenhum sentido nem direito" (Ibid.). Ou, como Heidegger não diz mas permite pensar, o "ente", não podendo "de direito" ser questionado quanto ao seu ser em si, ultrapassa por isso mesmo o limite da compreensão ontológica, permanecendo insondável por ela. Tratar-se-ia assim de duas posições antagônicas diante daquilo que, do ponto de vista de uma delas, constituiria o ontologicamente impossível: ou se o suprime enquanto quimera, resultado da confusão entre ser e ente, a mal afamada "entificação" do ser; ou se o assume como intangível pela compreensão de ser (seja tácita ou explícita, originária ou decadente), incomparavelmente mais inacessível que a coisa em si de Kant, que, enquanto "logicamente possível", ainda corresponde a uma espécie do pensável (cf. Kant, 1980, p. 175, B 347).

Diante dessa alternativa, cabe sem dúvida perguntar como a ontologia fundamental está efetivamente posicionada em relação àquilo que, por assim dizer, romperia a barreira do sentido. De que modo a compreensão de ser se situa frente ao não-ser de um 
ente, enquanto caráter pelo qual o "ente" se mantém inapropriável por todo possível compreender? Como ela poderia "aceitar" o não-ente, o que em si mesmo não "faz sentido" ("é" unsinnig)? Como lidaria com o que, potencialmente "contrassensual" (widersinnig), não se deixa assimilar sob uma possibilidade de existência, sendo, contudo, supostamente capaz de atingir o próprio ser do ser-aí e, com isso, determiná-lo de modo decisivo? Decerto, uma tal aceitação requereria da ontologia fundamental o questionamento da ideia (todavia, sustentada por Heidegger na preleção de 1928) de que "para o problema do ser em geral [... ] a questão central é a subjetividade do sujeito mesmo" (Heidegger, 1990, p. 194), ou seja, de que, em todo nexo ontológico, o ser do homem, o ser-aí, constitui o centro único de referência. Suposto que a compreensibilidade de tudo o que pode vir ao encontro, enquanto pré-formação de sua possibilidade ontológica no ser-aí, seja condição indispensável para a efetividade do projeto existencial, um eventual empenho na (não-)relação ao incompreensível não-ser de um ente demandaria do ser-aí humano simplesmente a suspensão da transcendência originária e, com isso, o abandono do posto de centralidade ontológica "em meio ao ente". Atingido por uma "impossível" potência de nãosentido, o ser-aí sofreria a queda irremissível no abismo do que jaz, não na periferia do ser (a natureza como "caso-limite do ser de um possível ente intramundano"), mas radicalmente fora dele (a natureza como extramundana).

É igualmente certo, entretanto, que Heidegger reconhece ser possível um conceito da natureza "em um sentido mais originário" do que como "objeto das ciências naturais", conceito segundo o qual "a natureza não se deixa encontrar nem no círculo do mundo circundante nem, em geral, primariamente como algo 
com o que nos relacionamos" (Id. 2004a, p. 155-156, nota 55). É o que lemos em uma importante nota do tratado Da essência do fundamento, inserida no contexto de uma exposição do conceito existencial de mundo por referência ao conceito antropológicotranscendental proposto por Kant, nota na qual Heidegger procura, de algum modo, justificar a "aparente" (scheinbar) omissão da natureza na analítica do ser-aí. Admitindo o silêncio de Ser e tempo a respeito, Heidegger pretende que haja "fundamentos" para isso e, mais ainda, que a própria "base para o problema da natureza" tenha sido efetivamente lançada pela ontologia fundamental (Ibid.). Ele dá a entender que tal base consiste na "unidade do conceito pleno do cuidado", à qual pertence como momento fundamental a facticidade (Faktizität) do ser-aí, afirmando explicitamente que é no fato de estar lançado a uma situação disposicional "em meio ao ente" que a natureza "se manifesta originariamente no ser-aí [im Dasein]" (Ibid.). Assim, ao invés de considerar a possibilidade, problematicamente ontológica, do extramundano, Heidegger parece, em sua justificativa para a omissão da natureza "em sentido mais originário", simplesmente reiterar a tese, lançada na passagem de Ser e tempo referida pela nota de 1929, de que a natureza - seja como "conjunto categorial de estruturas de ser de um determinado ente que vem ao encontro dentro do mundo" ou "no sentido do conceito de natureza do romantismo" ("o fenômeno 'natureza") "somente é apreensível a partir do conceito de mundo, isto é, a partir da analítica do ser-aî" e, por isso, não seria "jamais capaz de tornar compreensível a mundanidade" (Heidegger, 1993, p. 65). Portanto, se há uma natureza mais originária do que aquela que vem ao encontro, na condição de instrumento ou paisagem, dentro do mundo, ela não poderia ser compreendida 
como determinante do próprio ser-no-mundo, visto que este último é, para si mesmo, ontologicamente independente do extramundano e constituinte do intramundano (cf. Löwith, 2006, p. 224).

\section{Natureza e cultura}

Pudemos perceber, através do esclarecimento oferecido pelas três teses ontológicas enunciadas na preleção sobre os Princípios metafísicos da lógica, que a admissão da possibilidade ontológica da natureza não contraria, pelo menos não necessariamente, a ontologia do ente intramundano originalmente exposta em Ser e tempo. Como vimos, a afirmação do ser-em-si do ente pretende fundar-se justamente na ideia da precedência ontológica do mundo em relação ao que vem ao encontro dentro dele. Mas isso significa que, ao contrário de sugerir, com a tese "crítica" proposta nos Problemas fundamentais, a de que "a intramundanidade não pertence ao ser da natureza", a aceitação desta última em seu caráter problematicamente extramundano, Heidegger o rechaça como impossibilidade, "sem sentido nem direito" (Heidegger, 1990, § 10, p. 195). De fato, era simplesmente "de maneira precavida" que, na preleção de 1927, se permitira dizer que a intramundanidade não seria sequer uma "estrutura de ser". O que o filósofo pretende resguardar com a precaução em reformular essa ideia tão surpreendente quanto problemática, propondo em seu lugar que a intramundanidade apenas "não pertence ao ser da natureza"?

É precisamente isso o que se mostra na continuação da passagem do $\S 15$ dos Problemas fundamentais que comentávamos mais acima: Heidegger justifica o cuidado na formulação da tese sobre o ser da natureza argumentando que "precisamos contar 
aqui com uma restrição, na medida em que há ente que só é enquanto é intramundano" (Id. 2005, p. 241). Se se entendesse que a intramundanidade não consiste na estrutura de ser de um ente, mas sim apenas na forma ontológico-transcendental do encontro com o ente já dentro do mundo, não seria possível reconhecer o ser do ente que só pode "surgir e vir ao ser como intramundano" (Ibid.), que é "em si mesmo" determinado a partir do mundo: "Há ainda [além da natureza] o ente a cujo ser pertence, de certo modo, a intramundanidade" (Ibid.). De que ente se trata?

Esse ente é tudo o que denominamos ente histórico, histórico no sentido mais amplo do histórico-mundial [Weltgeschichtlich], isto é, o todo das coisas que o homem, o qual existe e é histórico no sentido próprio, cria, forma, cultiva, a cultura e as obras (Ibid.).

Trata-se, nos termos do $\S 73$ de Ser e tempo, do "secundariamente histórico", ou seja, do ente não-dotado do modo de ser do ser-aí, compreendido ontologicamente em vista da constituição do mundo histórico (Id. 1993, p. 381). Se Heidegger concede à natureza certa independência frente ao mundo, reconhecendo o seu suposto ser "em si" para além da intramundanidade, ele o faz tendo por objetivo estabelecer a diferença ontológica entre natureza e cultura ("A cultura não é como a natureza"; Heidegger, $2005, \S 15$, p. 241) e, com isso, o ser, inequivocamente intramundano, das obras culturais. No fundo, o que parece estar em jogo com a restrição da intramundanidade à cultura é a constituição de uma "ontologia da história" (Heidegger, 2005, § 15, p. 241) fundada na analítica existencial, ao invés de uma ontologia da natureza extramundana que recusasse esse fundamento. 
Duas razões corroboram esta leitura da passagem comentada dos Problemas fundamentais da fenomenologia. Em primeiro lugar, tem-se que, sendo "uma determinação necessária para a possibilidade de descoberta da natureza" (Heidegger, 2005, § 15, p. 240; grifo meu), a intramundanidade consiste no único modo, para o ser-aí humano, de encontrá-la. Se a natureza é ou não em si, no sentido de ser fora do mundo, o fato é que o ser-aí não poderia entrar em relação com ela senão no contexto ontológico em que, por princípio, tudo se orienta em função da formação do próprio mundo. Com isso, não haveria a possibilidade de o ser-aí ser determinado ou tornado compreensível, em seu existir, pela natureza; no mínimo, o ser-aí mesmo, não obstante lançado inexoravelmente a uma situação fática, jamais poderia reconhecer essa eventual determinação, a permanecer inefável.

Em segundo lugar, a capacidade de ser "também se o ser-aí não existe" não implica, para Heidegger, uma prerrogativa da natureza sobre a cultura, mas consiste em algo que a natureza compartilha com o ente cultural, a que a intramundanidade pertence essencialmente: "De outro lado, precisamos dizer que, uma vez que a obra da cultura, até mesmo o instrumento mais primitivo, é intramundana, ela se torna capaz de ser, também se não existe mais nenhum ser-aí histórico" (Heidegger, 2005, § 15, p. 241).

Ora, por mais que o ente "impropriamente" histórico, a obra cultural, seja caracterizado por "condições de ser inteiramente outras" (Heidegger, 2005, § 15, p. 241) que as do ente natural, o fato de que ambos têm em comum a possibilidade de ser em si, independentemente da existência de um ser-aí, indica fortemente que, ao falar do ser-em-si do ente, Heidegger pensa antes em conformidade com as teses enunciadas nos Princípios meta- 
físicos da lógica a partir de Leibniz (isto é, em acordo estrito com a ontologia de Ser e tempo), que no sentido problemático (paradoxalmente sugerido pela passagem de início comentada do $§ 32$ de Ser e tempo) da admissão de um elemento sem sentido e contrassensual, limite da compreensão ontológica e tão incompreensível quanto, talvez, incontornável por ela.

Mas, afinal de contas, o que poderia estar assim fora do ser, a ponto de impor-se como seu negativo, como não-ser, e mesmo como seu contrário, como contra-ser? Uma interpretação crítica poderia talvez confirmar que, apesar de sua aparente inefabilidade ("tiefsinnig"), esse elemento "fora do ser" (Agamben, 2007, p. 167) inclui, como inseparável da natureza viva, o próprio homem, tomado para além ou aquém de sua "essência eksistente" e insondável dentro dos limites da compreensão de ser ("mais além da diferença entre ser e ente"; Agamben, 2007, p. 167), o humano enquanto vivente (Lebewesen) e, como tal, mais do que simplesmente privado de mundo, verdadeiramente extramundano - a humanidade enquanto Naturereignis.

\section{A inumanidade do homem}

Contestando de todo uma tal hipótese, que se volta contra a possibilidade mesma da compreensão de ser, Heidegger declara, vinte anos após a elaboração de Ser e tempo, na Carta sobre o humanismo:

Em todo caso, os seres vivos são como são sem que estejam, desde o seu ser como tal, na verdade do ser e conservem, nesse estar, o essenciante de seu ser. Provavelmente, para nós, de todo ente que é, o ser-vivo é o mais difícil de pensar, pois ele é, de um lado, o mais 
proximamente aparentado a nós, mas, de outro, está ao mesmo tempo separado por um abismo de nossa essência ek-sistente. Em contrapartida, poderia parecer que a essência do divino fosse mais próxima a nós do que o [aspecto] dos seres-vivos que estranha, mais próxima em uma distância essencial que, enquanto distância, é por isso mesmo mais familiar à nossa essência existente do que o parentesco corpóreo, abissal, dificilmente pensável com o animal (Heidegger, 2004b, p. $326)$.

Embora o diga no contexto de uma polêmica com a tradição metafísica, que "pensa o homem a partir da animalitas e não pensa na direção de sua humanitas" (Heidegger, 2004b, p. 323), e continue a sustentar a tese, oriunda da analítica existencial, de que "o que atribuímos ao homem enquanto animalitas [...] se enraíza na essência da existência" (Heidegger, 2004b, p. 324), Heidegger parece reconhecer tanto uma possível limitação da ontologia fundamental, baseada no fato de que o ser-vivo "não está na verdade do ser", sendo por isso "dificilmente pensável", quanto, mais além, que o caráter da animalidade, apesar de insondável, afeta "o mais proximamente" o ser-aí humano. Não é precisamente isso o que sugere a ideia paradoxal de um "parentesco abissal" com o animal, na dimensão do corpo (Leib)?

Contudo, em que pese "todo o enigmático [alles Rätselhafte] do ser-vivo" (Heidegger, 2004b, p. 326), Heidegger é enfático na afirmação de que "o corpo do homem [der Leib des Menschen] é algo essencialmente outro que um organismo animal [ein tierischer Organismus]", e isso não apenas no sentido de ser essencialmente diverso do "corpo explicado cientificamente" (Heidegger, 2004b, p. 324). Tal diferença entre corpos refletiria 
uma distinção mais fundamental entre modos de ser: enquanto a "plantas e animais" "falta a linguagem" (Heidegger, 2004b, p. 326), esta, sendo originariamente humana, quer dizer, de "essência histórico-ontológica" (Heidegger, 2004b, p. 333), não é "exteriorização de um organismo" (Äusserung eines Organismus), nem "expressão de um vivente" (Ausdruck eines Lebewesens) (Heidegger, 2004b, p. 326). Assim, se cabe falar em um "parentesco abissal" do homem com o animal, o abismo que os separa volta-se como enigma tão somente sobre o animal - e não sobre o homem. Mesmo quando, nos Conceitos fundamentais da metafísica, o filósofo considera criticamente a tese da pobreza de mundo do animal, admitindo que "somente visto a partir do homem é que o animal é pobre de mundo" (Heidegger, 2010, § 63, p. 393) e, até mesmo, que "a vida é muito mais um domínio que tem uma riqueza de abertura [des Offenseins] que talvez o mundo humano não conheça de modo nenhum" (Heidegger, 2010, § 60-b, p. 371-372), tais considerações, apontando para a inefabilidade do vivente para o existente, só reforçam o abismo entre eles, sem implicar a admissão da animalidade do homem nem, muito menos, a da humanidade do animal.

Logo, à questão sobre "se a essência do homem repousa na dimensão da animalitas" (Heidegger, 2004b, p. 323), seja esta determinada cientificamente ou pensada de modo ontológicoexistencial, deve-se responder sempre de modo negativo. Mas isso não significa que, a propósito da ontologia de Ser e tempo, não se possa falar, em sentido problemático, de um recalque da animalidade na essência mesma do homem. É notável, a esse respeito, o fato de que, nessa obra, Heidegger emprega, para qualificar o vínculo fático do ser-aí com o ente não-dotado do seu modo de ser, o mesmo termo que, nos Conceitos fundamentais 
da metafísica, designa precisamente um "momento essencial da animalidade enquanto tal" (Heidegger, 2010, § 58-b, p. 348), a saber, o aturdimento (Benommenheit) como "condição de possibilidade para que o animal, segundo a sua essência, se comporte [sich benimmt] em um ambiente [Umgebung], mas nunca em um mundo [Welt]" (Heidegger, 2010, § 58-b, p. 347-348). Já no § 13 de Ser e tempo, lemos que "o ser-no-mundo é, como ocupação, tomado/aturdido [benommen] pelo mundo de que se ocupa" (Heidegger, 1993, § 13, p. 61). A flutuação do sentido do termo sugere que, no tratado de 1927, se tende a confundir modos de ser, existência decadente e vida animal, que o aprofundamento da ontologia existencial na preleção de 1929-30 levará a distinguir com precisão. Ela permite também entrever no conceito de facticidade de Ser e tempo como que um resto de natureza viva, a extinguir-se de todo, na Carta sobre o humanismo, com a afirmação do abismo ontológico entre humanitas e animalitas.

Com efeito, o liame entre natureza e vida fática é proposto explicitamente naquela importante nota de Da essência do fundamento que comentávamos acima: "A natureza é manifesta originariamente no ser-aí pelo fato de que ele existe como situadodisposto [als befindlich-gestimmtes] em meio ao ente" (Heidegger, 2004a, p. 155-156, nota 55). Logo antes, porém, Heidegger já se referia à situação ontológica da natureza junto ao ser-aí humano nos seguintes termos: "Ainda que sendo em meio ao ente e envolvido por ele, o ser-aí enquanto existente sempre já ultrapassou a natureza" (Heidegger, 2004a, p. 138-139). Compondo-se as duas passagens, é possível concluir que, se a natureza se manifesta de modo originário na existência, ela o faz como aquilo que, por ser dado faticamente, o ser-aí pode, por princípio, ultrapassar em vista de si mesmo. Conforme já vimos, consistindo 
na "obscura ligação original entre a essência ekstática do ser-aí e o ser do ente que não é do tipo do ser-aî" (Haar, 1990, p. 73), a própria facticidade (e, com ela, a "natureza manifesta originariamente no ser-aî") é possibilitada, em seu sentido mundano, pelo projeto existencial. E uma vez que este último se deixa compreender como ontologicamente anterior àquela, a "animalidade" do homem - por assim dizer, a sua inumanidade enquanto "ser" em vista de outrem, "devir-animal" (cf. Deleuze Guattari, 1997a) ${ }^{2}$ - deverá submeter-se, em favor da possibilidade da existência própria, à historicidade como caráter de ser exclusivamente humano.

\section{Anti-humanismo?}

Ao contrário, caso assumisse a facticidade como origem contraexistencial do possível, tomando-a como incompreensível pela força de autopossibilitação do ser-aí mas, ao mesmo tempo, como determinante do acontecimento histórico, a ontologia fundamental decerto recusaria toda filiação ao desígnio da Aufklärung, sem permitir ser confundida com mais uma eminente ma-

\footnotetext{
"'Se o humano é o semelhante ou o que nós partilhamos com os outros (senso dito comum), é forçoso admitir que não se encontra, em sentido forte, senão o 'não-humano', o 'inumano'. Sendo a humanidade o que cada um tem em comum com os outros, não é o que as pessoas têm de humano que nos desconcerta. Encontra-se alguém na medida em que este se debate ele mesmo com [il est lui-même aux prises avec] o não-humano, e se é si mesmo debatendo-se com esse não-humano nele. [...] Na relação com um animal, afirmamos forçosamente um 'mundo' que não é o nosso, possibilidades de vida e perspectivas sobre o mundo que nos são estrangeiras, e que não pressentimos sem terror. [...] Se o fora é no mundo, e não além; se ele é entre os seres e em seu seio, deve-se poder pensar relações exteriores enquanto puros encontros: é a uma tal exigência, imanentista, que o conceito de devir responde" (Zourabichvili, 1997, p. 3-5).
} 
nifestação do espírito da "época da imagem de mundo" (Zeit des Weltbildes). Mas convém aqui não subestimar o fato de que o termo Weltbild - empregado, na conferência de 1938 publicada em Holzwege, para designar a compreensão de mundo inaugurada pela época moderna da metafísica, na qual o homem assume expressamente o eminente estatuto ontológico de "centro de referência do ente enquanto tal" (Heidegger, 2003, p. 88) - comparece como um dos principais predicados com que se descreve o ser do ser-aí:

"O ser-aí transcende" significa: ele é, na essência de seu ser, formador de mundo [weltbildend], e, na verdade, "formador" no sentido múltiplo de que ele deixa o mundo acontecer, com o mundo se dá um aspecto (imagem) originário que propriamente não capta, embora [este] funcione como pré-imagem [Vor-bild] para todo ente manifesto, do qual cada ser-aí mesmo faz parte (Heidegger, 2004a, p. 158).

Em acordo com o uso ambíguo desse termo (a sugerir que a analítica existencial, aparentemente contra sua intenção mais própria, se situaria a si mesma, resolutamente, no contexto da época moderna da filosofia), fazem eco ao espírito dessa mesma época as palavras com que, em Ser e tempo, Heidegger passa à exposição da constituição fundamental da historicidade: "Ninguém nega que, no fundo, o ser-aí humano seja o 'sujeito' primário da história [das primäre "Subjekt" der Geschichte]" (Heidegger, 1993, § 73, p. 382). Trata-se de adesão irônica a um senso comum, ou declaração de compromisso com o espírito de toda uma época?

Inegavelmente, Heidegger insiste em afirmar a diferença que 
a ontologia de Ser e tempo guardaria em relação às "interpretações humanistas do homem" fundadas na metafísica moderna. A oposição (Gegensatz) ao humanismo é tomada, adverte na carta a Beaufret, "não por causa do homem, a fim de que a civilização e cultura se façam valer por meio do seu criar", mas sim "em vista da dignidade do ser e em favor do Da-sein, que o homem sustenta existindo" (Heidegger, 2004b, p. 329). Nem por isso, todavia, a crítica heideggeriana deixa de manifestar um decisivo pendor "humanista", que se revela, sobretudo, em relação ao que nela se compreende como não-humano. Mediante o rebaixamento ontológico da não-humanidade, a referida crítica visa justamente ao favorecimento da essência do homem:

[...] o pensamento em Ser e tempo é contra o humanismo. Porém, essa oposição não significa que tal pensar se bata para o lado contrário do humano [auf die Gegenseite des Humanen] e advogue o não-humano [das Inhumane], que ele defenda a inumanidade [Unmenschlichkeit] e degrade a dignidade do homem [des Menschen]. Pensa-se contra o humanismo porque ele não alça suficientemente alto a humanidade do homem [die Humanitas des Menschen] (Heidegger, 2004b, p. $330)$.

Mas será mesmo que a consideração filosófica do não-humano (das Inhumane, das Unmenschliche) - consideração que, dizemos nós, não implica por si mesma a "advogação da desumanidade" - seria mesmo prescindível para o esclarecimento da essência do homem? Suposto, contra Heidegger, que haja uma inumanidade própria ao homem como vivente, o propósito de elevar "suficientemente alto" a sua humanidade (contrastada, na 
Carta sobre o humanismo, precisamente à animalidade) requereria, mais além, a supressão ontológica da vida enquanto dimensão cooriginária do humano. De fato, como vimos acima, a elevação da humanitas como "lugar da verdade do ser em meio ao ente" (Heidegger, 2004b, p. 332) é explicitamente acompanhada, no pensamento heideggeriano, pela redução do vivente (sobretudo, daquele "mais proximamente aparentado a nós") a objeto do discurso "desumanizante" da metafísica. Precisamente tomada, essa crítica parece propor a alienação da inumanidade do homem, a ser operada juntamente com a exclusão da humanidade dos viventes não-humanos.

Essa mesma orientação espiritual é aprofundada no contexto das meditações "pós-metafísicas" do final dos anos 30, em franca oposição à "humanização do homem" (Vermenschung des Menschen) e à correlativa "antropomorfização do ente em seu todo" (Vermenschlichung des Seienden im Ganzen), ambas operadas, segundo Heidegger, pela determinação heteróclita da essência do homem "a partir do animal", como "animal dotado de razão":

A humanização do homem não é somente o fundamento da antropomorfização do ente em seu todo, mas sim, ao mesmo tempo, da deificação [Vergötterung] do mundo. Nessa figura insidiosa, o "antropologismo" alcança sua essência metafísica ilimitada.

Porém, como a humanização do homem se deixa superar [überwinden]? Somente a partir da decisão pela fundação da verdade do Ser [Seyn]. Com ela, o homem não se distingue apenas como ente em relação ao ente, mas também é transportado, por essa decisão, para dentro da clareira do Ser [Lichtung des Seins] e reunido antecipadamente com o Ser com fundo em uma 
apropriação, já acontecida porém ainda não aprofundada, da essência humana [Menschenwesens] pelo Ser. Mas, por meio da ressaltada com- e contraposição [die Zusammen- und Gegenstellung] exclusiva de Ser e homem, já não se decidiu pela distinção do homem, na medida em que ele se essencia na pertença à verdade do Ser e, conforme a isso, se expõe, de um modo ou de outro, como o ente que ele é, ou seja, se coloca frente ao ente em seu todo? (Heidegger, 1997, p. 153-154).

A última pergunta é respondida afirmativamente, com a ressalva de que o homem se constitui como "o verdadeiro guardião da verdade do ser mesmo" (Heidegger, 1997, p. 156) sob a condição de ser "a-propriado (zu-geeignet) à sua essência" pelo Ser enquanto "Apropriação" (Ereignis), "a qual se funda na propriedade do ser-aí e nela é guardada" (Heidegger, 1997, p. 155). Trata-se de uma inflexão que obedece à mesma lógica daCarta sobre o humanismo: para que a humanização (animalização) do homem e a antropomorfização (racionalização) do ente sejam superadas, é preciso experimentar a "a-propriação (Er-eignung) do homem" como "super-apropriação (Über-eignung) no Ser" (Heidegger, 1997, p. 163). Para tanto, invoca-se aí precisamente o primado ôntico-ontológico do ser-aí humano, pelo qual se lhe reconhece, de maneira expressa, uma relação privilegiada e exclusiva com o ser e, com isso, uma posição central em meio à totalidade do ente - o que implica, de imediato, o assujeitamento daquilo que se toma como não- ou impropriamente humano (a saber, como animal ou primitivo). Em sua controversa oposição ao humanismo metafísico, Heidegger fundamenta o "mito da dignidade exclusiva da natureza humana" (Lévi-Strauss, 2013, p. 53) no próprio Ser. Com esse antropocentrismo sublimado 
em ontocentrismo, o seu pretenso anti-humanismo não poderia ser mais mitigado.

\section{Entre mundos}

Para subverter o mito do "isolamento metafísico do homem" (Heidegger, 1990, § 10, p. 172) e o círculo de exclusão por ele instaurado ${ }^{3}$, não bastaria, é claro, contestar que o homem existente seja o "sujeito' primário da história”. Antes de mais nada, parece ser preciso pensar as relações entre humanidade e nãohumanidade em um sentido resolutamente contra-existencial, seguindo-se um caminho interditado pelo projeto filosófico de Ser e tempo (visto que este último está baseado na pressupo-

"Não foi, afinal, esse mito que fez a própria natureza a primeira mutilação, a qual viriam inevitavelmente seguir-se outras mutilações? Começou-se por cortar o homem da natureza e constituí-lo como um reino supremo. Supunha-se apagar desse modo seu caráter mais irrecusável, qual seja, [o de que] ele é primeiro um ser vivo. E permanecendo cegos a essa propriedade comum, deixou-se o campo livre para todos os abusos. Nunca antes do termo destes últimos quatro séculos de sua história, o homem ocidental percebeu tão bem que, ao arrogar-se o direito de separar radicalmente a humanidade da animalidade, concedendo a uma tudo o que tirava da outra, abria um ciclo maldito. E que a mesma fronteira, constantemente empurrada, serviria para separar homens de outros homens, e reivindicar, em prol de minorias cada vez mais restritas, o privilégio de um humanismo corrompido de nascença, por ter feito do amor-próprio seu princípio e noção"(Lévi-Strauss, 2013, p. 53). Limitamo-nos aqui a discutir, no que se refere à filosofia de Heidegger, apenas um dos aspectos do "ciclo maldito"denunciado por Lévi-Strauss: o aspecto antropocêntrico, relativo à separação essencial entre humanidade e não-humanidade. $\mathrm{O}$ outro aspecto do ciclo, relativo à segregação de outros povos humanos, foge ao escopo do presente ensaio, devendo ser objeto de um outro estudo (em elaboração), no qual se pretenderá considerar o etnocentrismo da ontologia fundamental, evidente, por sua vez, nas oposições traçadas por Heidegger entre historicidade e primitividade, filosofia e mito (cf. especialmente Heidegger, 1993, § 11, p. 50-52, e Heidegger, 1996, §§ 41-46, p. 357-401). 
sição da existência própria, liberta de toda confusão com o não-existente, como "fundamento ôntico" para a consideração do ser enquanto tal; Heidegger, 2005, § 5, p. 26). Ao que tudo indica, a própria Seinsfrage teria que ser posta em suspenso por um pensamento que experimentasse como problemático o que, segundo Heidegger, "ninguém nega": o antropocentrismo do conceito ontológico da história, bem como o ontocentrismo do conceito existencial de humanidade. Pois, de modo contrário à privação redutiva do não-humano ("sem mundo", "pobre de mundo"), essa suspensão implica conferir um sentido completamente outro, isto é, um verdadeiro sentido de alteridade, a tudo aquilo que, no discurso sobre o ser, é rebaixado ao nível da impossibilidade ontológica, por ser tomado como adversário da constituição do sentido em geral. Abrir-se-ia, assim, nada menos que a possibilidade de uma reversão da história enquanto formação do mundo humano frente a outros mundos, de que o homem, existindo em vista de si mesmo, jamais poderia ser formador:

Diferentemente da noção heideggeriana de ontologia como um modo humano de ser-no-mundo, na afirmação de acima [a de que a "partição ontológica entre Natureza e Cultura" constitui "uma possibilidade em meio a uma hoste de ontologias (ou mundos) que concebem entidades e suas relações de maneiras muito diferentes"], ontologia se refere às práticas que promulgam diferenças entre entes em um mundo e as relações que os conectam e desconectam. Práticas heterogêneas de distribuição de diferença e as relações que delas se seguem fazem mundos heterogêneos (De La Cadena, 2012, p. 2). 
Situada nesse plano de heterogeneidade e divergência entre mundos, a ontologia revela, pois, um sentido de fato mais profundo (tiefsinnig), porém certamente não inefável: o que, para Heidegger, constitui a relação ontológica originária, a relação entre homem e ser - o sentido -, mostra-se indissociável de uma vinculação "contrassensual" (widersinnig), política, entre humanidade e não-humanidade, "ou melhor", entre diferentes povos humanos e não-humanos.

Tal qual a paz perpétua invocada por Kant, talvez o Ser mesmo jamais tenha consistido em um ponto de convergência universal ou de mediação diplomática entre os mundos em conflito, mas, bem antes, como território da humanidade ocidental, em um monstruoso "impedimento ao devir dos povos sujeitados" (Deleuze Guattari, 1997b, p. 140) ${ }^{4}$.

\section{Referências bibliográficas}

AGAMBEN, G. Lo abierto: el hombre y el animal. Trad. Flávia Costa e Edgardo Castro. Buenos Aires: Adriana Hidalgo Editora, 2007.

DE LA CADENA, M. "Seminar Proposal - Indigenous Cosmopolitics: Dialogues about the Reconstitution of Worlds". Sawyer Seminar on the Comparative Study of Cultures (University of California, Davis), 2012. Disponível em: http:// sawyerseminar.ucdavis.edu/files/2012/01. Acesso em: 01/05/ 2015.

DELEUZE, G. GUATTARI, F. "1730 - Devir- intenso, deviranimal, devir- imperceptível..." In: DELEUZE, G. GUATTARI, F. Mil platôs - capitalismo e esquizofrenia, vol. 4. Trad.

\footnotetext{
${ }^{4}$ Para um desenvolvimento dessa hipótese, cf. Valentim, 2013.
} 
Suely Rolnik. São Paulo: Editora 34, 1997a, pp. 11-113.

Alonso Muñoz. Rio de Janeiro: Editora 34, 1997b.

HAAR, M. Heidegger et l'essence de l?homme. Grenoble: Jérôme Millon, 1990.

HEIDEGGER, M. Gesamtausgabe, II. Abteilung: Vorlesungen 1923-1944, Band 26: Metaphysische Anfangsgründe der Logik im Ausgang von Leibniz. Frankfurt am Main: Vittorio Klostermann, 1990.

_-_. Gesamtausgabe, I. Abteilung: Veröffentlichte Schriften 1910-1976, Band 3: Kant und das Problem der Metaphysik. Frankfurt am Main: Vittorio Klostermann, 1991. 1993. Sein und Zeit. 17. Aufl. Tübingen: Max Niemeyer, Gesamtausgabe, II. Abteilung: Vorlesungen 1919-1944, Band 2\%: Einleitung in die Philosophie. Frankfurt am Main: Vittorio Klostermann, 1996.

. Gesamtausgabe, III. Abteilung: Unveröffentlichte Abhandlungen - Vorträge - Gedachtes, Band 66: Besinnung. Frankfurt am Main: Vittorio Klostermann, 1997.

. "Die Zeit des Weltbildes". In: HEIDEGGER, M. Holzwege. Frankfurt am Main: Vittorio Klostermann, 2003. . "Vom Wesen des Grundes". In: HEIDEGGER, M. Wegmarken. Frankfurt am Main: Vittorio Klostermann-Seminar, 2004a.

. "Brief über den Humanismus". In: HEIDEGGER, M. Wegmarken. Frankfurt am Main: Vittorio Klostermann-Seminar, 2004b.

Main: Vittorio Klostermann-Seminar, 2005. 
_-_. Die Grundbegriffe der Metaphysik: Welt-EndlichkeitEinsamkeit. Frankfurt am Main: Vittorio Klostermann-Rote Reihe, 2010.

KANT, I. Crítica da razão pura. Trad. Valerio Rohden e Udo Baldur Moosburger. São Paulo: Abril Cultural (Os Pensadores), 1980.

- Idéia de uma história universal de um ponto de vista cosmopolita. Trad. Rodrigo Naves e Ricardo R. Terra. Edição bilíngue. São Paulo: Brasiliense, 1986.

LÉVI-STRAUSS, C. "Jean-Jacques Rousseau, fundador das ciências do homem". In: LÉVI-STRAUSS, C. Antropologia estrutural dois. Trad. Beatriz Perrone-Moisés. São Paulo: Cosac Naify, 2013, pp. 45-55.

LÖWITH, K. Heidegger, pensador de un tiempo indigente. Sobre la posición de la filosofía en el siglo XX. Trad. Román Setton. Buenos Aires: Fondo de Cultura Económica, 2006.

VALENTIM, M. A. "Naturereignisse: Heidegger e o extramundano". In: WU, R. NASCIMENTO, C. R. (orgs.). A obra inédita de Heidegger. São Paulo: Liber Ars, 2012a, pp. 133150.

M. A. "A inumanidade do homem: Heidegger e o enigma do acontecimento". In: VEIGA, I. S. SCHIO, S. M. (orgs.). Heidegger e sua época: 1920-1930. Porto Alegre: Clarinete, 2012b, pp. 173-197.

_-_. "Extramundanidade e sobrenatureza". Natureza $\mathrm{Hu}$ mana, v. 15(2), pp. 48-93, 2013.

"Heidegger e o mito da filosofia". O Que Nos Faz Pensar, v. 35, pp. 27-60, 2014.

ZOURABICHVILI, F. "Qu'est-ce qu'un devenir, pour Deleuze?" Conférence prononcée à Horlieu (Lyon) le 27 mars $199 \%$. 
